\title{
Larvacidal Effect of Imperata Cylindrical Root Decoction against Culex sp. Larvae
}

Afini Tiara Resi ${ }^{1}$, Diah Dhianawaty D. ${ }^{2}$, Neneng Syarifah $S .^{3}$

${ }^{1}$ Faculty of Medicine, Universitas Padjadjaran, ${ }^{2}$ Department of Biochemistry, Faculty of Medicine, Universitas Padjadjaran, ${ }^{3}$ Department of Parasitology, Faculty of Medicine, Universitas Padjadjaran, Bandung, Indonesia

\begin{abstract}
Background: Filariasis is one of the neglected tropical diseases. About 337 of 401 districts in Indonesia are endemic areas for filariasis, especially in Sumatera, Kalimantan, and Papua. Culex sp. is one of the lymphatic filariasis vectors which can be controlled by insecticide, including larvacide. This study was conducted to determine the larvacidal effect of Imperata cylindrical root decoction against Culex sp. larvae.

Methods: This study was conducted at the Laboratory of Parasitology, Faculty of Medicine, Universitas Padjadjaran during the period of September to November 2012. The study object was Culex sp. larvae III/IV instars. The design of this study was experimental laboratory using true experimental approach. The larvae were divided into three groups: negative control (distilled water), reference (Abateß), and decoction. The number of larvae in each group was 25 larvae, and the effects were evaluated by the total number of dead larvae in 48 hours under observation. The data were then analyzed by Mann-Whitney test and Probit test.

Results: The result of the Mann-Whitney test to compare Imperata cylindrica root decoction treatment to distilled water as control was significant $(\mathrm{p}<0.05)$. However, Abate $\AA$ gave a better result. The Probit test result was $\mathrm{LC}_{50}: 63 \%$ and $\mathrm{LC}_{90}: 489 \%$.

Conclusions: Imperata cylindrical root decoction has a larvacidal effect against Culex sp. larvae [AM].2014;1(2):70-4]

Keywords: Culex sp., Filariasis, Imperata cylindrica (L.) Beauv., Larvacidal, $\mathrm{LC}_{50}$

\section{Pengaruh Larvasida Rebusan akar alang-alang (Imperata Cylindrical) terhadap Larva Nyamuk (Culex sp.)}

\begin{abstract}
Abstrak
Latar Belakang: Filariasis merupakan salah satu penyakit tropis yang terabaikan. Sekitar 337 dari 401 kabupaten di Indonesia adalah daerah endemik untuk filariasis terutama di Sumatera, Kalimantan, dan Papua. Nyamuk (Culex Sp.) adalah salah satu vektor filariasis limfatik yang dapat dikendalikan oleh insektisida, termasuk larvasida. Penelitian ini dilakukan untuk mengetahui pengaruh larvasida dari rebusan akar alang-alang terhadap larva nyamuk (Culex sp.)

Metode: Penelitian ini dilakukan di Laboratorium Parasitologi, Fakultas Kedokteran, Universitas Padjadjaran selama periode September-November 2012. Objek penelitian adalah larva nyamuk (Culex sp.) instar III / IV. Desain penelitian ini adalah eksperimental laboratoris dengan menggunakan pendekatan eksperimental yang benar. Larva dibagi menjadi tiga kelompok: kontrol negatif (air suling), referensi (Abate $($ ), dan rebusan. Jumlah larva dalam setiap kelompok adalah 25 larva, dan efek dievaluasi dengan jumlah total larva mati dalam 48 jam di bawah pengawasan. Data kemudian dianalisis dengan uji Mann-Whitney dan uji Probit. Hasil: Hasil uji Mann-Whitney untuk membandingkan pemberian rebusan akar alang-alang (Imperata cylindrica) terhadap air suling sebagai kontrol adalah signifikan $(\mathrm{p}<0,05)$. Namun, Abate $\AA$ memberikan hasil yang lebih baik. Hasil tes Probit adalah $\mathrm{LC}_{50}: 63 \%$ dan $\mathrm{LC}_{90}: 489 \%$.

Simpulan: Rebusan akar alang-alang (Imperata cylindrical) memiliki efek larvsidal terhadap larva nyamuk (Culex sp.) [AMJ.2014;1(2):70-4]
\end{abstract}

Kata kunci: Nyamuk (Culex sp.), Filariasis, Alang-alang (Imperata cylindrica (L.) Beauv), Larvasida, LC $_{50}$

Correspondence: Afini Tiara Resi, Faculty of Medicine, Universitas Padjadjaran, Jalan Raya Bandung-Sumedang Km.21, Jatinangor, Sumedang, Indonesia, Phone : +62 87805726372, Email : afini.tiararesi12@gmail.com 


\section{Introduction}

Filariasis is one of the neglected tropical diseases in the world. ${ }^{1,2}$ Data from the Ministry of Health of the Republic of Indonesia show that out of 401 districts/cities in Indonesia, 337 are still endemic for filariasis. ${ }^{3}$ Culex sp. is one of the filariasis disease vectors that carries Wuchereria bancrofti, Brugia malayi and Brugia timori parasites. ${ }^{4,5}$ Abate $®$ is one of the larvacides used to reduce the spread of filariasis vector due to its ability to kill mosquito larvae. ${ }^{4}$ However, the long -term use of Abate $\AA$ will lead to resistance in some mosquitoes, including Culex sp. mosquitoes. ${ }^{6}$ This resistance can occur in various ways and through different mechanisms. ${ }^{4}$ Therefore, there is a need for a new larvacide with less effects on human health but effective to kill larvae.

Imperata cylindrica is one of the most troublesome weeds in the world7 but the root extraction from this weed has several benefits for health thatthis weed is classified into one of the medicinal plants. 8 The root extraction from I. cylindrica contains flavonoid and tannin. The levels of flavonoids in I. cylindrica is $0.32 \%$ while for tannin it is $9.20 \%$.9 Sudjari et al. (2006) cited that flavonoids and tannins have mosquito larvacide effect and each has different mechanisms to kill the larvae.10 The method for processing the I. cylindrical root'in this experiment was decoction. This method is more suitable for roots with hard texture because decoction procedure needs more time during boiling than infusion. ${ }^{11}$

\section{Methods}

The study was conducted at the Laboratory of Parasitology, Faculty of Medicine, Universitas Padjadjaran during the period of September to November 2012 . The study was conducted in 3 weeks. The objects of the study were Culex sp. larvae III/IV instars. The design of this study was experimental laboratory research, with true experimental approach. The objects of this study were assigned into one of the three groups: treatment group, positive control group, and negative control group. The characteristics for both groups were homogenous.12 Randomization was performed in both treatment group and control group.

The Inclusion criterion for this experimental study was Culex sp. larvae III/
IV instars, while the exclusion criterion was Culex sp. larvae in moribund state. According to WHO criteria, the number of larva in each container should be 25 Culex sp. larvae III/ IV instars. ${ }^{14}$ The number of larvae needed in this experiment was 675 larvae. Details of larva count: 8 containers at preliminary test 1,4 containers at preliminary test 2 , and 15 containers at final test.

There were 2 types of variable used in this study, which were independent and dependent variables. The independent variable for this study was the concentration of I. cylindrica root decoction while the dependent variable was the larvacidal effect occurred in the experiment. The larvacidal effect was assessed from the number of larvae died or the number of larvae in a moribund state. ${ }^{12}$

The experiment was started by preparing the instruments and materials, including containers, disposable cups, a decoction set, pipettes, data recording forms, distilled water, I. cylindrica (L.) Beauv roots, Abate ${ }^{\circledR}$, larvae, and larvae food. Roots of the I. cylindrica were taken from the Arboretum UNPAD during the period of 26 September to 10 October 2012. The roots were collected when the plant was not flowering. The decoction process was started by weighing the fresh roots of 500 grams. The roots were sliced into small pieces $(2 \mathrm{~cm})$ and then boiled in $500 \mathrm{ml}$ of distilled water using a stainless steel pot (decoction set). The boiling process was performed for 30 minutes with a temperature of 900C. The thirty minutes started when the temperature had reached 900C.11 The root decoction solution was divided into a number of concentrations (100 ml volume) and was used immediately. Larvae were fed with mice food until they reached third or fourth instars. Larvae were divided into 3 groups of samples: the treatment group, negative control group and positive control group.

Three steps were used in this experiment. The first step was the preliminary test for screening the larvacidal effect of $I$. cylindrica root decoction when the larvae were exposed to negative control (distilled water) and several root decoction solution concentrations $(15 \%, 30 \%, 45 \%, 60 \%, 75 \%$, $90 \%$, and $100 \%$ concentrations). The most effective concentration was then re-tested in a follow up experiment. The next step was the subsequent test when the larvae were exposed to the negative control (distilled water), and 3 concentrations of root decoction solution which included were the most effective concentration from the previous test with an 
Table 1 Data from Preliminary Test and Subsequent Test

\begin{tabular}{ccccccccccc}
\hline \multicolumn{1}{c}{ Preliminary Test } & \multicolumn{3}{c}{ Subsequent Test } \\
\hline Control & $15 \%$ & $30 \%$ & $45 \%$ & $60 \%$ & $75 \%$ & $90 \%$ & $100 \%$ & Control & $95 \%$ & $100 \%$ \\
0 & 5 & 11 & 7 & 9 & 14 & 12 & 20 & 0 & 12 & 18 \\
\hline
\end{tabular}

addition and subtraction of 5\% concentration (most effective concentration, most effective concentration plus $5 \%$, and most effective concentration minus 5\%) The most effective concentration from this second step was then re-tested in the final test. Only 1 concentration of I. cylindrical root decoction was tested in the final test with 5 repeated tests. The results were then compared to the positive control group (Abate $\AA$ ) and negative control group (distilled water). The control group was also tested 5 times. ${ }^{12}$

The larvae tested were kept in containers. Each container consisted of 25 Culex sp. larvae and was observed for 48 hours. Every hour, the number of dead larvae was recorded. The observation was carried out until all larvae died or in a state of near-death (moribund state). Larvae were considered dead or in moribund state if they did not respond to stimulation (making reflex motion), which were touch and water splash simulations. the concentration that killedmost larvae or that kill all larvae most rapidly was considered to be the most effective concentration. ${ }^{12}$

The larvae in this study were provided with food because the experiment would be conducted in a quite long time period. The food was especially provided when there was an increase in mortality in the negative control group.14 The containers were kept at a room temperature (25-280C), with 12 hours of light, followed by 12 hours without light (12L:12D). ${ }^{12}$

The data analysis was conducted using SPSS 15.0 software. Hypothesis testing for numerical comparative data to determine the larvacidal effect of the root decoction was done from final experimental data. The data was initially tested using KolmogorovSmirnov test to determine the normality of data distribution. If the $p$-value $<0.05$, the data distribution is considered not normal which led to the use of the Mann-Whitney test. Meanwhile, if the $p$-value $>0.05$, meaning that the data distribution is normal, unpaired t-test should be used. To determine the value of the LC50 and LC90, data were obtained from the preliminary test 1 . The analyzes were performed using the Probit Test. ${ }^{12}$

\section{Results}

The preliminary test was conducted in week 1 and the subsequent test was performed in week 2. From both tests, I. cylindrical root decoction in $100 \%$ concentration showed the highest mortality, so it was re-tested in a final experiment.

The Kolmogorov-Smirnov test was conducted on final experiment data. All data had a significance value of below 0.05 , showing abnormal variations in all data. The effect of larvacide was then compared using a non-parametric test, i.e. Mann-Whitney test (Table 3).

Table 2 Final Experiment Results

\begin{tabular}{cccc}
\hline Group & & $\begin{array}{l}\text { Number } \\
\text { Total } \\
\text { Larvae }\end{array}$ & $\begin{array}{l}\text { of Dead } \\
\text { Larvae } \\
\text { (48 } \\
\text { hours) }\end{array}$ \\
\hline $\begin{array}{c}\text { Imperata } \\
\text { cylindrical Root }\end{array}$ & 1 & 25 & 19 \\
Decoction (100\%) & 2 & 25 & 17 \\
& 3 & 25 & 16 \\
& 4 & 25 & 14 \\
Distilled Water & 5 & 25 & 16 \\
& 1 & 25 & 1 \\
& 2 & 25 & 0 \\
& 3 & 25 & 0 \\
& 4 & 25 & 1 \\
Abate $\circledR$ & 5 & 25 & 0 \\
& 1 & 25 & 25 \\
& 2 & 25 & 25 \\
& 3 & 25 & 25 \\
& 4 & 25 & 25 \\
& & 25 & 25 \\
\hline
\end{tabular}


Table 3 Mann-Whitney Test Results

\begin{tabular}{lccc}
\hline & Parameter & p-value (alpha=5\%) & Interpretation \\
\hline $\begin{array}{l}\text { 100\% Imperata } \\
\text { cylindrica root } \\
\text { decoction-Aquades } \\
\begin{array}{l}100 \% \text { Imperata } \\
\text { cylindrica root } \\
\text { decoction-Abate }\end{array}\end{array}$ & number of dead larvae & 0.00 & Significant \\
\hline
\end{tabular}

Table 4 Concentration Logarithm \& Probit Test Results

\begin{tabular}{cccccc}
\hline Mortality & Total Larvae & Concentration & Mortality (\%) & $\begin{array}{c}\text { Concentration } \\
\text { log }\end{array}$ & Probit \\
\hline 5 & 25 & 15 & $20 \%$ & 1.18 & 4.16 \\
11 & 25 & 30 & $44 \%$ & 1.48 & 4.85 \\
7 & 25 & 45 & $28 \%$ & 1.65 & 4.42 \\
9 & 25 & 60 & $36 \%$ & 1.78 & 4.64 \\
14 & 25 & 75 & $56 \%$ & 1.88 & 5.15 \\
12 & 25 & 90 & $48 \%$ & 1.95 & 4.95 \\
20 & 25 & 100 & $80 \%$ & 2.00 & 5.84 \\
\hline
\end{tabular}

It was clear that I. cylindrical root decoction has a larvacidal effect against Culex sp. Larvae. However, it can be affirmed that Abate ${ }^{\circledR}$ still has a better effect than the root decoction (Table 4).

The Probit model results, $Y=-2.402+$ $1.442 \mathrm{X}$, where $\mathrm{Y}$ is the probit, and $\mathrm{X}$ is the concentration log from I. cylindrical root decoction concentration (Table 4). From the probit model it was discovered that LC50 for I. cylindrica root decoction was $63 \%$ and LC90 was $489 \%$.

\section{Discussion}

Based on the results of this study, there The testing of larvacide effects of roots decoction needed 3 steps. Each step is conducted in 48 hours. An hourly observation is performed to count the dead larvae. The time needed for killing a half of the 25 larvae and to kill all larvae in 48 hours is the parameter to measure the larvacidal activity.

The data from the experiment was analyzed using SPSS software in this study. The first test was to test the normality of the data distribution using the Kolmogorov-Smirnov test. The results show that the data distribution for all groups was not normal $(\mathrm{p}<0.05)$; hence, non-parametric tests was selected for further analysis.

A non-parametric test for numericcomparative data (Mann-Whitney) was used in this study. The result shows that there were differences in larvacidal effects ( $p$-value $<0,05$ ) between $100 \%$ I. cylindrica root decoction and negative control (distilled water) and positive control (Abate $\left.{ }^{\circledR}\right)$. However, the larvacidal effects of root decoction on Culex sp. larvae are much smaller when compared to Abate ${ }^{\circledR}$ larvacidal effect.

The effective concentration for larvacide is determined by LC50 and LC90. LC50 and LC90 of I. cylindrica root decoction were counted using the Probit test, and the results were $63 \%$ for LC50 and $489 \%$ for LC 90 . This means that root decoction with $63 \%$ concentration is needed to kill 50\% larvae within 48 hours, while Abate ${ }^{\circledR}$ can kill all the larvae in 1 hour. In conclusion, I. cylindrica root decoction has a larvacidal effect against Culex sp. larvae third and fourth instars but the effect is less. The weak larvacidal effect of I. cylindrica root decoction is probably due to the small amount of flavonoids in the I. cylindrica root. There is also a possibility that the decoction method produces less than maximum amount of flavonoid that can be extracted. Therefore, a follow up study using a new method is needed to discover the active compounds 
in the I. cylindrica root that possibly has a larvacidal effect in addition to flavonoid and tannin. Another study may be conducted by using dried I. cylindrica roots. Dried roots can be used any time. Furthermore, a study using Aedes sp larvae is also important to assess the possibility to use I. cylindrica root decoction in preventing the disease transmitted by Aedes sp.

\section{References}

1. Perera M, Whitehead M, Molyneux D, Weerasooriya M, Gunatilleke G. Neglected patients with a neglected disease? a qualitative study of lymphatic filariasis. PLoS Negl Trop Dis. 2007;1(2):e128.

2. Kline K, McCarthy JS, Pearson M, Loukas A, Hotez PJ. Neglected tropical diseases of Oceania: review of their prevalence, distribution, and opportunities for control. PLoS Negl Trop Dis. 2013;7(1):e1755.

3. Departemen Kesehatan Republik Indonesia. Rencana Nasional Program Akselerasi Eliminasi Filariasis di Indonesia 2010-2014.Jakarta. KKRI;2010. [cited 2012 April 21]. Available from: http://www.pppl.depkes. go.id/_asset/_download/NATIONAL_ PLAN_FILARIASIS_2010-IND__2010-14. pdf

4. Natadisastra D, Agoes R. Parasitologi kedokteran: ditinjau dari organ tubuh yang diserang. Jakarta. Penerbit Buku Kedokteran EGC; 2009.p.150-60, 317, 359

5. Simonsen PE, Mwakitalu ME. Urban lymphatic filariasis. Parasitol Res. 2013;112(1):35-44.

6. Hamdan H, Sofian-Azirun M, Ahmad NW, Lim LH. Insecticide resistance development in Culex quinquefasciatus (Say), Aedes aegypti (L.) and Aedes albopictus (Skuse) larvae against malathion, permethrin and temephos. Trop Biomed. 2005;22(1):4552.

7. Miller JH. Nonnative invasive plants of Southern forests : a field guide for identification and control. Asheville: USDA; 2003.p.50-1. [Cited 2012 April 25]. Available from: http://www.srs.fs.usda. gov/pubs/viewpub.php?index $=5424$

8. Ahmad FB, Ismail G. Medicinal plants used by Kadazan dusun communities around Crocker Range. ASEAN Review of Biodiversity and Environmental Conservation (ARBEC);2003 [Cited 2012 April 25]. Available from: http://kdca.org. my/wp-content/files/medicinal_crange. pdf.

9. Ayeni KE, Yahaya SA. Phytochemical screening of three medicinal plants neef leaf (Azadirachta indica), hibiscus leaf (Hibiscus rosasinensis), and spear grass leaf (Imperata cylindrical). Continental J Pharmaceutical Sciences. 2010;4:47-50.

10. Sudjari, Iskandar A, Telussa AS. Pengaruh Dekok Daun Mint (Mentha arvensis var javanica) Sebagai Larvasida Nabati Nyamuk Anopheles sp di Pantai Balekambang, Kecamatan Bantur, Kabupaten Malang. Fakultas Pendidikan Kedokteran Universitas Brawijaya:Malang. 2005 [Cited 2012 May 10]. Available from: http://elibrary.ub.ac.id/ handle/123456789/18325

11. Suranto A. Khasiat \& Manfaat Madu Herbal. Jakarta: AgroMedia; 2004.p.87

12. WHO. Guidelines for laboratory and field testing of mosquito larvicides. Geneva.WHO;2005. [Cited 2012 April 22] Available from:http://whqlibdoc. who.int/hq/2005/WHO_CDS_WHOPES_ GCDPP_2005.13.pdf 